\title{
Planting Materials Seed Systems of Finger Millet, Rice and Taro in Jumla, Kaski and Bara Districts of Nepal
}

\author{
Bimal K Baniya ${ }^{1}$, Radha K Tiwari ${ }^{1}$, Pashupati Chaudhary ${ }^{2}$, Surendra K Shrestha ${ }^{1}$ and Pushpa R Tiwari ${ }^{2}$ \\ ${ }^{1}$ Nepal Agricultural Research Council, Khumaltar, PO Box 1135, Kathmandu, Nepal \\ ${ }^{2}$ Local Initiatives for Biodiversity, Research and Development (LI-BIRD), PO Box 324, \\ Pokhara, Nepal
}

\begin{abstract}
Formal and informal seed supply systems of rice (Jumla, Bara and Kaski), finger millet and taro (Kaski) were studied in three ecosites of Nepal during 1999-2001 to understand the processes of seed flow, seed production, seed selection and storage systems. A survey was conducted at 48 to 96 households. Informal seed supply was the only system in Jumla and Kaski and formal system existed only in Bara. The main sources of seed were farmer's own saved seed (67-91\%), seed from neighbors and relatives. Exchange of germplasm was the main basis of fulfillment from other sources. All farmers obtained seed from their own village, while farmers introduced materials occasionally from outside village. Most of the farmers followed seed selection before or after crop harvest. Rice field selection and plant selection based on a fixed set of criteria was the common practice. Non lodged plants with more grain per panicle, bold grains, well-matured and uniform plants, long panicle, true to type, good looking grains, free from diseases and insects were the main rice seed selection criteria. All farmers from both sites stored rice seeds by local methods in the locally available containers. Mor and Mudkothi are the special straw containers to store rice seed in Bara. Dhara is a special mud structure used to store rice seeds in Jumla. Finger millet seed supply system was mostly similar to that of rice seed system. Ninety one percent farmers saved seed for their own use; however, many of them changed finger millet seeds lots or varieties regularly for their particular plot. Ears selection during harvest by set criteria for seed purpose was the common practice. Farmers stored finger millet seed carefully in small locally available containers and tried their best to maintain the quality of seed during different stage of seed production. Taro has diverse planting materials: cormels, corms with eyes, suckers and corm with small cormels. Taro planting materials management is totally informal and almost $89 \%$ farmers saved these materials for their use and replaced them mostly after 3 years. Farmers had fixed criteria of corms and cormels selection for planting purpose and focus and more on disease free. Storage of planting materials was locally by using local materials and methods. Understanding of seed system in various crops helps to develop conservation strategy.
\end{abstract}

Key words: Seed flow, seed production, seed selection, seed storage, seed system

\section{INTRODUCTION}

Seed is the genetic material, which is the first link in the food chain, source of life, future plant and even source of culture (Shiva et al 1995). Both formal and informal seed supply systems exist in Nepal, but informal system is playing major role to fulfill the seed need (Baniya et al 1999). Traditional seed supply system is an important source of diversity for majority of farmers (Shrestha 1998). An understanding of farmers seed supply system is prerequisite to understand the on-farm germplasm conservation. Seed production, seed selection, seed flow and seed storage practices followed by farmers have the high impact on the genetic diversity. Similarly, some farmers procure seeds of different crops and their varieties from formal and informal systems and ultimately increase the diversity at species and 
variety levels. Bellon and Smale (1998) clarified the concepts of seed flows, varietal choice, seed selection and seed management. The units of seed flow are often referred to as seed lots (Louette and Smale 1996). The seed supply system of landraces is totally informal, which has not well understood and after the CBD - 1992 agreement, it is getting priority from national and international levels.

To study the seed supply system in Nepal, 3 sites were selected one site each at high hill in Jumla, mid hill in Kaski and plain area in Bara districts. Jumla site is situated in the altitudinal range of 2240 to $3000 \mathrm{~m}$ on both sides of Tila river. The climate of Jumla site is cool temperate to sub-alpine and the average annual rainfall is $886 \mathrm{~mm}$. The altitudinal range of Bara is 80 to $90 \mathrm{~m}$, its climate is tropical to subtropical and the average annual rainfall is $1515 \mathrm{~m}$. The Kaski site is situated at Begnas and Rupa lake watershed areas whose altitudinal range is 600 to $1600 \mathrm{~m}$; its climate is subtropical with average rainfall $3979 \mathrm{~mm}$ (Paudel et al 1999). Rice is the main crop of Jumla site and 17 rice landraces are reported from there. Similarly, 53 (33 local +20 modern) rice varieties were reported from Bara. Finger millet is the important food crop in hills, but it is neglected crop and Nepal is rich in finger millet diversity (Baniya et al 1992). A total of 24 landraces were reported (Rana et al 2000b) from Kaski site. Taro is a clonally propagated crop and common vegetable in Kaski site. In taro also 24 landraces were reported from the study site. The main objective of this study was to understand the informal seed supply system of finger millet, rice and taro grown at different ecological zones of Nepal; and suggest to improve the local seed system.

\section{MATERIALS AND METHODS}

A questionnaire with 21 questions was prepared for rice seed supply system in Jumla and Bara. Some information of site selection and base line survey of in-situ project were used to select the particular household (Rana et al 2000a, 2000b, 2000c). Out of the rice growing HHs, 48 houses were surveyed based on the criteria of wealth rank, rich, medium and poor (Table 1) and gender groups, male and female. Thus six categories consisting of rich male and female; medium male and female; poor male and female were formed and eight houses were randomly selected from each group. To estimate the sources of seed, seed production techniques, seed selection methods, seed storage system, seed flow, seed counseling etc.

Table 1. Status of rice, finger millet and taro growing households (HH) in Jumla, Kaski and Bara, 1998

\begin{tabular}{|c|c|c|c|c|c|}
\hline \multirow[t]{2}{*}{ SN } & \multirow[t]{2}{*}{ Variable } & Jumla & \multicolumn{2}{|c|}{ Kaski } & \multirow{2}{*}{$\begin{array}{l}\text { Bara } \\
\text { Rice }\end{array}$} \\
\hline & & Rice & Finger millet & Taro & \\
\hline 1 & Total number of HH's & 759 & 941 & 941 & 914 \\
\hline \multirow[t]{5}{*}{2} & No. of HH's used in ba & & & & \\
\hline & 1) Rich & 40 & 77 & 77 & 21 \\
\hline & 2) Medium & 59 & 74 & 74 & 73 \\
\hline & 3) Poor & 81 & 55 & 55 & 108 \\
\hline & Total & 180 & 206 & 206 & 202 \\
\hline \multirow[t]{5}{*}{3} & No. of HH's growing c & & & & \\
\hline & 1) Rich & 40 & 60 & 66 & 21 \\
\hline & 2) Medium & 59 & 53 & 49 & 73 \\
\hline & 3) Poor & 81 & 33 & 32 & 103 \\
\hline & Total & 180 & 146 & 146 & 197 \\
\hline \multirow[t]{5}{*}{4} & No. of HH's used in se & & & & \\
\hline & 1) Rich & 16 & 32 & 32 & 16 \\
\hline & 2) Medium & 16 & 32 & 32 & 16 \\
\hline & 3) Poor & 16 & 32 & 32 & 16 \\
\hline & Total & 48 & 96 & 96 & 48 \\
\hline
\end{tabular}

Source: Rana et al 2000a, 2000b and 2000c. 
In case of finger millet, the questionnaire developed for rice was modified to suite the finger millet. The basic data and information of site selection and base line survey were used for selecting specific household (Rana et al 2000a, 2000b, 2000c). Out of 146 finger millet growing farmers in Kaski, 60 were rich, 53 medium and 33 poor. Each group was divided into male and female. After putting the farmers into 6 cells, 16 farmers were randomly selected from each cell and 96 households were surveyed (Table 1).

In case of taro also the questionnaire developed for rice was modified. Taro growing farmers (Pandey et al 1998) were divided into six categories. Out of 146 taro-growing farmers, 65 were rich, 49 medium and 32 poor. Each group was divided into male and female and 16 farmers were randomly selected from each cell. So, 96 households were surveyed to collect information on different aspects of taro planting material supply system. The data were analyzed with the help of SPSS package.

\section{RESULTS}

\section{Seed flow}

\section{Rice in Jumla}

About 79 percent farmers saved rice seed by themselves. Similarly, relatives and neighbors also were supplying rice seed to the farmers. Few farmers even received seed from extension agents, however there was no formal rice supply system in Jumla (Table 2). Most of the farmers from Jumla had no practice of changing seed. About 33 percent farmers followed seed change in the regular interval (Table $3)$.

Table 2. Number and percentage of households in receiving seed and planting material of rice, finger millet and taro in Jumla, Kaski and Bara, 2000

\begin{tabular}{|c|c|c|c|c|c|c|c|c|}
\hline \multirow[t]{3}{*}{ Source of seed } & \multicolumn{4}{|c|}{ Rice } & \multirow{2}{*}{\multicolumn{2}{|c|}{$\begin{array}{r}\text { Finger millet } \\
\text { Kaski } \\
\end{array}$}} & \multirow{2}{*}{\multicolumn{2}{|c|}{$\begin{array}{l}\text { Taro } \\
\text { Kaski }\end{array}$}} \\
\hline & & Jumla & & Bara & & & & \\
\hline & $\mathrm{N}$ & Percent & $\mathrm{N}$ & Percent & $\mathrm{N}$ & Percent & $\mathrm{N}$ & Percent \\
\hline Own & 42 & 79 & 31 & 67 & 87 & 91 & 85 & 89 \\
\hline Neighbour & 6 & 11 & 5 & 11 & 21 & 22 & 21 & 23 \\
\hline Relative & 4 & 8 & 3 & 7 & 3 & 3 & 8 & 8 \\
\hline Formal & - & - & 6 & 13 & - & - & - & - \\
\hline Others (extension) & 1 & 2 & 1 & 2 & - & - & - & - \\
\hline
\end{tabular}

Table 3. Number and percentage of households in replacing seed of respective crops in Jumla, Kaski and Bara, 2000

\begin{tabular}{|c|c|c|c|c|c|c|c|c|}
\hline \multirow[t]{3}{*}{ Period } & \multicolumn{4}{|c|}{ Rice } & \multicolumn{2}{|c|}{ Finger millet } & \multicolumn{2}{|c|}{ Taro } \\
\hline & & Jumla & & Bara & & Kaski & & Kaski \\
\hline & $\mathrm{N}$ & Percent & $\mathrm{N}$ & Percent & $\mathrm{N}$ & Percent & $\mathrm{N}$ & Percent \\
\hline No change & 32 & 67 & 1 & 2 & 17 & 18 & 16 & 17 \\
\hline Every year & 11 & 23 & 1 & 2 & 2 & 2 & 1 & 1 \\
\hline Every 2-3 year & 3 & 6 & 28 & 58 & 17 & 18 & 18 & 18 \\
\hline More than 3 year & 2 & 4 & 18 & 38 & 60 & 62 & 62 & 64 \\
\hline
\end{tabular}

\section{Rice in Bara}

In Bara, about $67 \%$ farmers saved their own rice seed. Formal system was the second main source of seed and followed by neighbours and relatives (Table 2). Almost all farmers replaced seed in the regular interval (98\%). Changing rice seed in every three year was very common practice (Table 3). Neighbors, relatives, market and public sector were the sources of seed and exchange, gift, purchase and free 
distribution were the main bases of rice seed flow. Rice seed flow took place inside and outside the village.

\section{Finger millet in Kaski}

Majority of farmers (91\%) saved their own seed for their use. Some of the farmers managed finger millet seed from their neighbors and relatives (Table 2). Purchase, exchange, gift and free collection of seed are the bases of seed flow. Almost $82 \%$ farmers had the practice of changing seed in the regular interval (Table 3). About 62\% farmers changed seed lot in more than 3 years period. This was done mostly either by female or both sexes.

The surveyed 96 farmers cultivated finger millet in about 18.5 ha area and used $371 \mathrm{~kg}$ of seed (seed rate $20 \mathrm{~kg} / \mathrm{ha}$ ). The recommended seed rate of finger millet is $10 \mathrm{~kg} / \mathrm{ha}$, so the farmers are using almost double the required amount of seed, which might be due to the difficulties in managing finger millet seedlings in dry and stress conditions. So, farmers are using more seed in obtaining sufficient seedlings even in adverse climatic conditions.

\section{Taro in Kaski}

About $89 \%$ farmers used their own source of planting materials, $23 \%$ bring these from their neighbors and $8 \%$ from their relatives. Some farmers mentioned more than one sources of cormels. Nobody was bringing the seed from formal system (Table 2). When the sources of cormels for seed purpose is from neighbors, the farmers either purchase the cormels or receive them freely. Exchange was negligible and generally they provide cormels to the relatives as gift. Almost $83 \%$ farmers changed the seed lot or even variety regularly. Majority of farmers (64\%) followed this practice after 3 years only.

The main planting material of taro is cormel and corm and suckers in some cases. The surveyed 96 farmers cultivated taro in about 0.906 ha and used about $1141 \mathrm{~kg}$ cormels as planting material. The seed rate of taro is about $1260 \mathrm{~kg} / \mathrm{ha}$, which seems that farmers are using the required seed rate (recommendation 1000 to $1600 \mathrm{~kg} / \mathrm{ha}$ and spacing is $50-\times 30-\mathrm{cm}$ ). Estimated area and planting materials of taro is vague for farmers, because area is small and generally seed is not measured as in rice or finger millet.

\section{Seed production}

\section{Rice in Jumla}

Most of the farmers (about 96\%) followed seed selection process either before or after harvesting the crop, and some farmers followed seed selection before and after harvesting the crop. About 58\% farmers selected the best patch of rice field, harvested the crop separately and keep for the seed (Table 4). Some farmers simply harvested the crop, threshed and kept separately the required amount of seed from the whole harvest. Farmers had fixed a set of criteria for seed selection from standing crop. Well matured plants, free from insects and diseases, bold and big grain, uniform plants, better panicle, etc were the main selection criteria before harvesting and free from diseases and insects, clean and better grain, bold grains, long panicles, etc were the main criteria after harvesting (Table 5).

\section{Rice in Bara}

The farmers of this site had not separate place for seed production but about $40 \%$ farmers fixed better area in the rice field and followed seed selection only before or after and both before and after harvesting. Some farmers practiced panicle selection in the standing crop. However, the very common method of seed selection in Bara was that first, farmers harvested the crop of the previously fixed area, dried few days in the field, prepared the bundles from the crop, transported to the threshing flour and removed off types from the bundles and threshed separately for seed purpose (Table 4). Free from 
diseases and insects, bold seed, non lodged plants, uniform plants and panicles, true to type, bright and better panicles, etc were rice seed selection criteria before harvesting and true to type, free from insects and diseases, uniform plants and panicles, big and bold seeds, etc were the criteria of seed selection after harvest (Table 6).

Table 4. Number and percentage of households following the seed and planting material selection of rice, finger millet and Taro in Jumla, Kaski and Bara, 2000

\begin{tabular}{|c|c|c|c|c|c|c|c|c|c|}
\hline \multirow[t]{3}{*}{ SN } & \multirow[t]{3}{*}{ Process } & \multicolumn{4}{|c|}{ Rice } & \multirow{2}{*}{\multicolumn{2}{|c|}{$\begin{array}{c}\text { Finger millet } \\
\text { Kaski }\end{array}$}} & \multirow{2}{*}{\multicolumn{2}{|c|}{$\begin{array}{c}\text { Taro } \\
\text { Kaski } \\
\end{array}$}} \\
\hline & & \multicolumn{2}{|c|}{ Jumla } & \multicolumn{2}{|r|}{ Bara } & & & & \\
\hline & & $\mathrm{N}$ & Percent & $\mathrm{N}$ & Percent & $\mathrm{N}$ & Percent & $\mathrm{N}$ & Percent \\
\hline 1 & Selecting panicles or plants from the whole area & 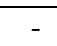 & - & 6 & 13 & 40 & 42 & 1 & 1 \\
\hline 2 & $\begin{array}{l}\text { Selection of panicles or plant from the best patch } \\
\text { of area }\end{array}$ & 28 & 58 & 1 & 2 & 52 & 54 & 2 & 2 \\
\hline 3 & $\begin{array}{l}\text { Harvesting all and selecting seed from the whole } \\
\text { lot after threshing }\end{array}$ & 12 & 25 & 4 & 8 & - & - & - & - \\
\hline 4 & $\begin{array}{l}\text { Selection of better ears/panicles/cormels after } \\
\text { harvesting the crop }\end{array}$ & 6 & 13 & 30 & 63 & - & - & 75 & 78 \\
\hline 5 & Planting the left over after using for food & - & - & 1 & 4 & - & - & 2 & 2 \\
\hline 6 & No response & 2 & & 6 & & 4 & & 16 & \\
\hline
\end{tabular}

Table 5. Number and percentage of households in seed selection criteria of rice before and after harvesting in Jumla, 2000

\begin{tabular}{llrrrr}
\hline SN & Selection criteria & Before harvest & \multicolumn{2}{r}{ After harvest } \\
\cline { 3 - 6 } & & $\mathrm{N}$ & Percent & $\mathrm{N}$ & Percent \\
\hline 1 & Well matured plant & 28 & 38 & - & - \\
2 & Bold and big seed & 13 & 18 & 18 & 26 \\
3 & Free from insects and diseases & 11 & 15 & 15 & 22 \\
4 & Uniform plants with better panicles & 7 & 9 & - & - \\
5 & Clean and better plant type/seed & 4 & 5 & 12 & 17 \\
6 & True to type & 3 & 4 & - & - \\
7 & Long panicle & 2 & 3 & 3 & 4 \\
8 & Free from weed plants/seeds & 2 & 3 & 1 & 1 \\
9 & Cleaner than food grain & & - & 8 & 12 \\
10 & Others (less shattering, less moisture, etc.) & 4 & 5 & 13 & 18 \\
\hline
\end{tabular}

Same farmers practiced more than one criteria.

\section{Finger millet in Kaski}

Majority of farmers followed seed selection practices. Many farmers followed seed selection during the harvesting of finger millet and the some did this activity before harvest. The general practices of seed selection was that during harvesting some experienced farmers first harvest some ears for seed purpose and keep separately for each variety. This is very common practice in case of finger millet, because varietal mixture is common, and few ears will be sufficient for seed purpose. The farmers either select the better ears from the whole field or first select better area and select the better ears from the fixed area only (Table 4). Farmers had their own selection criteria and followed accordingly. Big ear size, free from finger blast, well matured ears, big grain size, free from insects and non lodged plants were the major seed selection criteria (Table 7). About 88\% female make decision to fix the criteria and the decision of male was negligible (Table 7).

Farmers are very much careful in maintaining of seed quality during harvesting, threshing, drying, storing and planting of finger millet. The main strategy of maintaining seed quality was keeping the seed lot separately from other seed or food purpose finger millet grains. Harvesting earlier than others, threshing without heaping the ears, threshing by hand and leg, more drying than food grain, store in air tied container, were other regular activities to maintain seed quality. 
Table 6. Number and percentage of households in seed selection criteria of rice before and after harvesting in Bara, 2000

\begin{tabular}{|c|c|c|c|c|c|}
\hline \multirow[t]{2}{*}{ SN } & \multirow[t]{2}{*}{ Selection criteria } & \multicolumn{2}{|c|}{ Before harvest } & \multicolumn{2}{|c|}{ After harvest } \\
\hline & & $\mathrm{N}$ & Percent & $\mathrm{N}$ & Percent \\
\hline 1 & Free from diseases and insects & 10 & 26 & 14 & 16 \\
\hline 2 & Big and bold seeds & 8 & 21 & 13 & 15 \\
\hline 3 & Uniform plants, panicles and grains & 5 & 13 & 12 & 14 \\
\hline 4 & Non lodging plants & 4 & 10 & 4 & 5 \\
\hline 5 & True to type & 3 & 8 & 16 & 19 \\
\hline 6 & Long and better panicles & 3 & 8 & 7 & 8 \\
\hline 7 & Bright and better panicles & 3 & 8 & & - \\
\hline 8 & Removal of off types (Rouging) & 1 & 3 & & - \\
\hline 9 & Panicum with more grains & 1 & 3 & 1 & 1 \\
\hline 10 & Removal of off type grains & - & - & 5 & 6 \\
\hline 11 & Uniform grain colour & - & - & 2 & 2 \\
\hline 12 & Not damaged by rain & - & - & 2 & 2 \\
\hline 13 & Well matured plants & - & - & 3 & 4 \\
\hline 14 & $\begin{array}{l}\text { Others (not wet grain, plants from the } \\
\text { center of heap, protects from mixing, etc) }\end{array}$ & - & - & 7 & 8 \\
\hline
\end{tabular}

\section{Taro in Kaski}

About $81 \%$ farmers followed seed selection procedures (Table 4). 93\% farmers followed cormel selection during or after the harvest of the crop. Due to the underground nature of the crop, selection before harvest is difficult and very few farmers followed cormel selection before harvesting. Few farmers followed cormels selection even during planting time. Less eyed, non damaged, diseases and insects free and big sized cormels were the main seed selection criteria (Table 8). Either female (72\%) or both male and female (27\%) were the decision maker to fix taro cormels selection criteria (Table 8). Few farmers kept cormels intact with its mother corm for seed purpose. Farmers had no plan to select seed from better crop area, however they harvest the crop from the whole field and select cormels from the harvested lot. Few farmers did not bother for seed selection. Taro is generally cultivated in association with ginger, cowpea, sweet potato and maize in upland. It was not understood the effect of other crops on cormel production by this cultivation practice.

Table 7. Number and percentage of households with the decision makers in adopting major criteria of finger millet seed selection in Kaski, 2000

\begin{tabular}{llrrrrr}
\hline SN & Selection criteria & \multicolumn{3}{c}{ Decision makers, $\mathrm{n}$} & \multicolumn{2}{c}{ Total } \\
\cline { 3 - 6 } & & Male & Female & Both & $\mathrm{N}$ & Percent \\
\hline 1 & Big ear size & 2 & 69 & 9 & 80 & 83 \\
2 & Free from finger blast & 1 & 63 & 5 & 69 & 72 \\
3 & Well matured ears & - & 38 & 6 & 44 & 46 \\
4 & Big grain size & - & 23 & 1 & 24 & 25 \\
5 & Free from insects & - & 18 & 1 & 19 & 20 \\
6 & Non lodged plants & - & 16 & 1 & 19 & 20 \\
7 & Disease free plants & 1 & 12 & 2 & 15 & 16 \\
8 & Non dried leaves and stems & - & 4 & 1 & 5 & 5 \\
9 & True to type & - & 3 & 3 & 6 & 6 \\
10 & No finger branching ears & - & 2 & - & 2 & 2 \\
11 & No response & - & 3 & - & 3 & 3 \\
\hline Total & Number & 2 & 84 & 10 & 96 & - \\
& Percent & 2 & 88 & 10 & - & 100 \\
\hline
\end{tabular}

Some farmers followed more than one criteria. 
Table 8. Number and percentage of households with the decision makers in adopting major criteria of taro planting materials selection in Kaski, 2000

\begin{tabular}{llrrrrr}
\hline \multirow{2}{*}{ SN } & \multicolumn{3}{c}{ Selection criteria } & \multicolumn{2}{c}{ Decision makers, $\mathrm{n}$} & \multicolumn{2}{c}{ Total } \\
\cline { 3 - 7 } & Male & Female & Both & N & Percent \\
\hline 1 & Less eyed cormels & 1 & 24 & 8 & 33 & 34 \\
2 & Non diseased and damaged cormels & - & 20 & 12 & 32 & 33 \\
3 & Free from insects and diseases & - & 23 & 8 & 31 & 32 \\
4 & Not mechanically damaged cormels & 1 & 23 & 6 & 30 & 31 \\
5 & Bigger cormels on time & - & 22 & 5 & 27 & 28 \\
6 & Not damaged by white grub & 1 & 18 & 7 & 26 & 27 \\
7 & Small size cormels for seed economy & 1 & 15 & 6 & 22 & 23 \\
8 & Planting the sprouted ones & - & 6 & 4 & 10 & 10 \\
9 & Better looking cormels & - & 6 & 4 & 10 & 10 \\
10 & Storing in better place & - & 5 & 4 & 9 & 9 \\
11 & Not wrinkled cormels & 1 & 2 & 2 & 5 & 5 \\
12 & Storing in Tauwa & - & 1 & 2 & 3 & 3 \\
13 & Others (less dried, cormels intact with corm & - & 2 & 1 & 3 & 3 \\
& etc.) & & & & & 17 \\
\hline 14 & No response & 1 & 69 & 26 & 96 & - \\
\hline Total & Number & 1 & 72 & 27 & - & 100 \\
\hline
\end{tabular}

Some farmers followed more than one criteria.

\section{Seed storage}

\section{Rice in Jumla}

Earthen Dhara, wooden Bhakari, drum and small pots were the main containers for rice seed storage (Table 9). Farmers took extra care to store rice seed by adopting special methods and approaches (Table 10). Separate harvesting, threshing, cleaning, drying and storing in closed containers and more drying were the strategies to keep seed pure and high quality. Storing the seed in bright, cold and dry places in the raised portion, insects and diseases free places were common practices (Table 10).

\section{Rice in Bara}

Mud-kothi, jute sacks, plastic bags, drum, Mor etc are the seed storage structure and containers. Mudkothi or Kothi was the very common structure made for seed storage of different crops (Table 9). Mudkothi is a temporary structure placed outside or inside the house, which is made by local materials and plastered by mud. Mor is another special type of container made from rice straw by tying long and strong straw together. It is especially made for rice seed, storing capacity of which ranges from 20 to 40 kg. Farmers reported that the seed stored in Mor will remain fresh and dry easily. Mor is kept inside or outside house in the raised portion. Some people put mud on the outside of the Mor. The seed containers are either kept at the raised portion or Machan or above bricks bed inside the room.

\section{Finger millet in Kaski}

The requirement of finger millet seed for the individual farmers is less, where average quantity was about $3.9 \mathrm{~kg} /$ household, minimum $0.44 \mathrm{~kg}$ and maximum $14 \mathrm{~kg}$. So, farmers had not devised any container for finger millet storage. However, they stored finger millet seed in small earthen pots (Ghaito, Gagri), wooden vessel (Theki), bamboo container (Dalo), tin vessel, small plastic bags, etc. (Table 9). Farmers were careful to cover the mouth of the containers and some farmers mixed millet seed and black gram seed together and stored. Perhaps this is followed to store black-gram seed safely than finger millet seed. For seed purpose, the grain is dried 2 to 3 times more and is stored in smoking place in air tied containers (Table 10). 
Table 9. Number and percentage of households using different containers/structures in storing rice and finger millet seeds and taro planting materials in Jumla, Kaski and Bara, 2000

\begin{tabular}{llrrrrrrrr}
\hline \multirow{2}{*}{ SN } & Containers/Structures & \multicolumn{4}{c}{ Rice } & \multicolumn{3}{c}{ Finger millet } & \multicolumn{2}{c}{ Taro } \\
\cline { 3 - 9 } & & \multicolumn{3}{c}{ Jumla } & Bara & & Kaski & \multicolumn{1}{c}{ Kaski } \\
\cline { 3 - 9 } & Earthen Dhara & Percent & N & Percent & N & Percent & N & Percent \\
\hline 2 & Wooden Bhakari & 8 & 71 & - & - & - & - & - & - \\
3 & Lead drum & 2 & 4 & - & - & - & - & - & - \\
4 & Mudkothi & - & - & - & - & 7 & 7 & - & - \\
5 & Jute bag & - & - & 10 & 21 & 8 & 8 & - & - \\
6 & Bag + Mudkothi & - & - & 7 & 15 & - & - & - & - \\
7 & Plastic bag & - & - & 5 & 10 & 20 & 21 & - & - \\
8 & Bag + drum & - & - & 4 & 8 & - & - & - & - \\
9 & Small earthen pot (Ghaito) & - & - & - & - & 68 & 71 & - & - \\
10 & Water vessel (Gagri) & - & - & - & - & 19 & 20 & - & - \\
11 & Big basket (Doko) & - & - & - & - & - & - & 48 & 0.5 \\
12 & Wooden structure (Khol) & - & - & - & - & - & - & 23 & 24 \\
13 & Straw Tauwa & - & - & - & - & - & - & 16 & 17 \\
14 & Others (wooden Dhara, small pot, & 4 & 8 & 4 & 8 & 29 & 30 & 16 & 17 \\
& Mor, earthen pot, Theki, dalo, etc.) & & & & & & & & \\
15 & No response & - & - & - & - & 2 & 2 & 10 & 10
\end{tabular}

Some farmers used more than one containers.

\section{Some local storage \\ Khol $=$ Special structures made from small pieces of woods. \\ Doko = Big basket made from the bamboo which is used to carry bulk material like grasses, fodders etc. Mach $($ Machan $)=$ Temporary structure made by locally available materials which is above the ground. \\ Tauwa $=$ Small structure like Mach where the straw or other agriculture materials are kept. \\ Ghaito $=$ Small earthen pot made for carrying water . \\ Gagri $=$ Medium earthen or metal pot used to transport water by a person. \\ Theki $=$ Wooden vessel made for handling milk and curd.}

\author{
Dalo = Small bamboo container made for keeping \\ things. \\ Bhakari = Big bamboo container for storing grain . \\ Kotho $=\quad$ Small bamboo container for \\ storing grain. \\ Dharo $=$ Special small structure made by mud and \\ kept either above stone or wood. \\ Mudkothi = Temporary structure made by local \\ material and plastered by mud which is placed \\ inside or outside the house. \\ Mor = Special container made from rice straw itself \\ by tying long and strong straw together.
}

\section{Taro in Kaski}

Storing in big bamboo basket (Doko) was the most common method followed by wood structure (Khol), Tauwa (heap of straw) and so on (Table 9). Cormels for seed purpose were buried inside the soil for sprouting before planting. While storing for the seed purpose, farmers stored cormels in separate places and materials, some stored in wet places even inside the locally made pits. However, some farmers store the seed and food cormels in the same place and even in the same container (Table 10). Cormels for seed purpose was dried less and store them in the better places, The leaves, petioles, corms and cormels are the edible parts of taro and these are used for making varieties of foods. The seed storage methods for different crops in different places were not the same, which might be due to diverse nature of the crops and studied places. 
Table 10. Number and percentages of households in paying special attention in storing seed and planting material of rice, finger millet and Taro in Jumla, Kaski and Bara, 2000

\begin{tabular}{|c|c|c|c|c|c|c|c|c|c|}
\hline \multirow[t]{3}{*}{$\mathrm{SN}$} & \multirow[t]{3}{*}{ Methods } & \multicolumn{4}{|c|}{ Rice } & \multirow{2}{*}{\multicolumn{2}{|c|}{$\begin{array}{r}\text { Finger millet } \\
\text { Kaski }\end{array}$}} & \multicolumn{2}{|c|}{ Taro } \\
\hline & & \multicolumn{3}{|c|}{ Jumla } & \multirow{2}{*}{$\begin{array}{r}\text { Bara } \\
\text { Percent }\end{array}$} & & & & Kaski \\
\hline & & $\mathrm{N}$ & Percent & $\mathrm{N}$ & & $\mathrm{N}$ & Percent & $\mathrm{N}$ & Percent \\
\hline 1 & Storing in bright, cold and dry place & 37 & 55 & - & - & - & - & - & - \\
\hline 2 & $\begin{array}{l}\text { Storing on wood, stone and mud } \\
\text { raised places }\end{array}$ & 8 & 12 & - & - & - & - & - & - \\
\hline 3 & $\begin{array}{l}\text { Storing in insects, rats and diseases } \\
\text { free places }\end{array}$ & 7 & 10 & - & - & - & - & - & - \\
\hline 4 & Storing in dark and hot place & 6 & 9 & - & - & - & - & - & - \\
\hline 5 & $\begin{array}{l}\text { Keeping in the mouth closed } \\
\text { structures above raised portion inside } \\
\text { the room }\end{array}$ & 9 & 13 & - & - & - & - & - & - \\
\hline 6 & $\begin{array}{l}\text { Containers are kept above brick } \\
\text { inside room }\end{array}$ & - & - & 28 & 59 & - & - & - & - \\
\hline 7 & Keep in Machan & - & - & 12 & 25 & - & - & - & - \\
\hline 8 & Containers above floor & - & - & 4 & 8 & - & - & - & - \\
\hline 9 & Storing in smoky place & - & - & - & - & 6 & 6 & - & - \\
\hline 10 & Storing in air tied container & - & - & - & - & 3 & 3 & - & - \\
\hline 11 & Seed mixed with other grains & - & - & - & - & 1 & 1 & - & - \\
\hline 12 & Storing in small containers & - & - & - & - & 52 & 54 & - & - \\
\hline 13 & Drying more than food grain & - & - & - & - & 16 & 17 & & \\
\hline 14 & Keeping in separate place & - & - & - & - & 3 & 3 & 12 & 13 \\
\hline 15 & Storing in separate containers & - & - & - & - & - & - & 37 & 39 \\
\hline 16 & No different from food & - & - & - & - & - & - & 29 & 30 \\
\hline 17 & Storing in separate structure $(\mathrm{Khol})$ & - & - & - & - & - & - & 13 & 15 \\
\hline 18 & Planting cormels buried in pits & - & - & - & - & - & - & 2 & 2 \\
\hline 19 & $\begin{array}{l}\text { Others (Away from children, dry } \\
\text { more, keep on woods, wet place etc.) }\end{array}$ & 1 & 1 & 4 & 8 & 4 & 4 & 8 & 8 \\
\hline 20 & No response & - & - & - & - & 11 & 12 & 5 & 5 \\
\hline
\end{tabular}

Some farmers fallow more than one methods.

\section{DISCUSSION}

The rice seed production system in Bara was well-managed and advanced as compared to that of Jumla. Farmers of Bara managed seeds from different sources, changed the seed lot more frequently and followed fixed criteria of seed selection. The seed supply system of finger millet had many similarities with rice seed system and much dissimilarity as compared to that of taro. Kaski farmers are trying their best to produce better quality finger millet seed by practicing extensive seed selection procedures, careful performance of agronomical practices and storage processes for pure seed. Farmers are paying extra attention to select blast free finger millet seed. Taro is different crop from the other crops in terms of uses, propagation, cultivation practices and bulkiness of its cormels. So, the seed flow pattern, seed production and storage practices of taro were very much different than other crops. There is need to control borer in taro. It is expected that the indigenous knowledge and practices related to seed and planting material supply system of rice, finger millet and taro will be helpful to formulate their conservation strategies in future. Again, findings of this study will be useful to the development agents to intervene in the seed system for improvement and thereby developing the agriculture system. 


\section{REFERENCES}

Baniya BK, A Subedi, RB Rana, CL Paudel, SP Khatiwada, DK Rijal and BR Sthapit. 1999. Informal rice seed supply and storage systems in mid-hills of Nepal. In: A scientific basis of in situ conservation of agrobiodiversity on-farm: Nepal's contribution to global project (B Sthapit, M Upadhyay and A Subedi, eds). NP Working Paper No 1/99. NARC, LI-BIRD and IPGRI, Nepal. Pp. 79-91.

Baniya BK, KW Riley, DMS Dongol and KK Sherchand. 1992. Characterization of Nepalese hill crops landraces (barley, buckwheat, finger millet, grain amaranth, foxtail, proso and barnyard millets). NARC-IBPGR, Kabre, Dolakha, Nepal.

Bellon MR and M Smale. 1998. A conceptual framework for valuing on-farm genetic resources. CIMMYT, Mexico.

Louette D and M Smale. 1996. Genetic diversity and maize seed management in traditional Mexican community for in situ conservation of maize. CIMMYT, Mexico.

Pandey YR, DK Rijal and B Sthapit. 1998. Diversity of taro and on-farm conservation through use in Nepal. Paper presented in the symposium on "Ethno botanical and genetic study of taro diversity in China: Approaches for the conservation and use of taro genetic resources" from 10-12 November 1998 held at Laiyang Agricultural University. Shangdong, China.

Paudel CL, P Chaudhary, DK Rijal, SN Vaidya, PR Tiwari, RB Rana, D Gauchan, SP Khatiwada, SR Gupta and BR Sthapit. 1999. Agrogoecosystem factors for in situ conservation of agrobiodiversity in different ecozones of Nepal. In: A scientific basis of In-situ conservation of agrobiodiversity on-farm: Nepal's contribution to the global project (B Sthapit, M Upadhyay and A Subedi, eds). NP Working Paper No 1/99. NARC, LI-BIRD and IPGRI.

Rana RB, CL Paudel, PR Tiwari, D Gauchan, A Subedi, BR Sthapit, MP Upadhyay and DI Jarvis.2000c. In situ crop conservation: Findings of agro-ecological crop diversity and socio-economic baseline survey of Talium eco-site, Jumla, Nepal. NP Working paper No 3/2000. NARC/LI-BIRD, Nepal/IPGRI, Rome, Italy.

Rana RB, DK Rijal, D Gauchan, BR Sthapit, A Subedi, MP Upadhyay, YR Pandey and D Jarvis. 2000b. In situ crop conservation: Findings of agro-ecological, crop diversity and socio-economic baseline survey of Begnas eco-site, Kaski, Nepal. NP working paper No 2/2000. NARC/LIBIRD, Nepal/IPGRI, Rome, Italy.

Rana RB, P Chaudhary, D Gauchan, SP Khatiwada, BR Sthapit, A Subedi, MP Upadhyay and DI Jarvis. 2000a. In situ crop conservation: Findings of agro-ecological, crop diversity and socio-economic baseline survey of Kachorwa eco-site, Bara, Nepal. NP Working Paper No 1/2000. NARC/LI-BIRD, Nepal/IPGRI, Rome, Italy.

Shiva V, V Ramprasad, P Hedge, O Krishna, R Holla-Bhar. 1995. The seed keepers. NAVDANYA. The Research Foundation for Science, Technology and Nature Research Policy. New Delhi, India.

Shrestha PK, 1998. Gene, gender and generation: Role of traditional seed supply system in the maintenance of agrobiodiversity in Nepal. In: Managing Agrobiodiversity, Farmers' changing perspective and Institutional Responses in the Hind-Kush Himalayan Region (T Pratap and B Sthapit, eds). IPGRI, ICIMOD, Kathmandu, Nepal. Pp.143-152. 